\title{
GROUNDWATER CONTAMINATION RISK MAPPING IN URBAN WATERSHED
}

https://doi.org/10.4215/rm2020.e19013

\author{
Filipe da Silva Peixoto a*
}

(a) Dr. em Geologia. Professor da Universidade do Estado do Rio Grande do Norte (UERN), Mossoró (RN), Brasil.

ORCID: https://orcid.org/0000-0001-5409-3001. LATTES: http://lattes.cnpq.br/5905976485635222.

\author{
Article history: \\ Received 06 July, 2019 \\ Accepted 09 April, 2020 \\ Publisher 15 June, 2020
}

(*) CORRESPONDING AUTHOR

Address: UERN. Av. Prof. Antônio Campos, s/n. CEP 59610-210, Mossoró (RN) Brasil.

E-mail: fpeixoto10ufc@gmail.com

\begin{abstract}
Groundwater contamination cause different risks to society, promoting rise of the disease's cases, in addition to reduce the hydric disponible and to degrade the aquifers, that are strategic reservoir to hydric sustainability of society. Therefore, this study was aimed to applies the groundwater contamination risk index - IRCAS, identifying they efficiency in indication/prediction of water contamination in a urban watershed on Fortaleza City/Brazil. For this, we applied the vulnerability aquifer model GOD to set natural susceptibility and to match environment sanitation index - ISA for to produce the IRCAS. For identify the efficiency this model, we accomplish 2 field campaign, one at the end of the rainy season (July), and other in dry season (November), to analyzed physics and chemistry parameters of groundwater collected of the wells. The major contamination was caused to nitrate, that presented 53 and $46 \%$ of the sample out of potability standard on rainy and dry period, respectively. The variance analyses ANOVA report model efficiency of 61 and $54 \%$ of explication of the nitrate contamination variance for on rainy and dry period, respectively.
\end{abstract}

Keywords: Aquifer vulnerability, Water protection and conservation, Urban waters, Urban aquifer.

\section{Resumo / Resumen}

\section{RISCO DE CONTAMINAÇÃo DA ÁGUA SUBTERRÂNEA EM UMA SUB-BACIA URBANA}

A contaminação da água subterrânea inflige variados riscos à sociedade, promovendo aumento de casos de doenças, além de diminuir a disponibilidade hídrica e degradar os aquíferos, que são estratégicos para a sustentabilidade hídrica da sociedade. O objetivo desse trabalho foi aplicar o Índice de Risco de Contaminação da Agua Subterrânea - IRCAS, identificando sua eficiência na indicação/predição de contaminação da água subterrânea em uma sub-bacia urbana na cidade de Fortaleza/Brasil. Para isso, foi aplicado o modelo de vulnerabilidade aquífera GOD, para determinar a susceptibilidade natural, e então combinar com o Índice de Saneamento Ambiental - ISA para realizar o IRCAS. Para identificar a eficiência do modelo foram realizadas 2 campanhas de campo, uma no final do período chuvoso em julho e outro no período seco em novembro, para analisar parâmetros físicos e químicos da água subterrânea coletada dos poços. O parâmetro mais problemático em termos de contaminação foi o nitrato, que apresentou 53 e $46 \%$ das amostras fora dos padrões de potabilidade para período chuvoso e período seco, respectivamente. A análise de variância - ANOVA apresentou que o modelo possui eficiência de explicar 61 e 54\% da variância contaminação por nitrato para período chuvoso e período seco, respectivamente.

Palavras-chave: Vulnerabilidade aquífera, Conservação e proteção das águas, Águas Urbanas, Aquíferos urbanos.

\section{MAPEO DEL RIESGO DE CONTAMINACIÓN DE AGUAS SUBTERRÁNEAS EN UNA SUBCUENCA URBANA}

La contaminación de las aguas subterráneas causa diferentes riesgos para la sociedad, promoviendo el aumento de los casos de enfermedades, además de reducir la disponibilidad hídrica y degradar los acuíferos, que son un reservorio estratégico para la sostenibilidad hídrica de la sociedad. Por lo tanto, es importante La contaminación del agua subterráneo inflige varios riesgos en la sociedad, promoviendo el aumento de casos de enfermedades, más allá de disminuir la disponibilidad hídrica y degradar los acuíferos, que son estratégicos para la sustentabilidad hídrica de la sociedad. El objetivo de este trabajo fue aplicar el Índice de Riesgo de Contaminación del Agua Subterráneo - IRCAS, identificando su eficiencia en la indicación/ predicción de contaminación del agua subterráneo en una subcuenca urbana en la ciudad de Fortaleza/, Brasil. Para eso, fue aplicado el modelo de vulnerabilidad acuífero GOD, para determinar la susceptibilidad natural, y entonces, combinar con el Índice de Saneamiento Ambiental - ISA para realizar el IRCAS. Para realizar la eficiencia del modelo, se realizaron dos investigaciones de campo, uno en el final del periodo lluvioso en julio y otro en el periodo seco en noviembre para poder analizar los parámetros físicos y químicos del agua subterráneo colectados en las pozas. El parámetro más problemático en termino de contaminación fue el nitrato, que presentó 53 y $46 \%$ de las muestras fuera de los padrones de potabilidad para el periodo lluvioso y seco respectivamente. El análisis de varianza - ANOVA mostró que el modelo posee eficiencia de explicar 61 y $54 \%$ de la varianza de contaminación por el nitrato para el periodo lluvioso y seco respectivamente.

Palabras-clave: Vulnerabilidad de acuífero, Conservación y protección de las aguas, Aguas urbanas, Acuíferos urbanos. 


\section{INTRODUCTION}

Aquifers located under cities face well-recognized complex problems, due to the considerable pollution load that has to be incorporated into the groundwater and which can contaminate this resource and make its use unfeasible. Schirmer, Leschik, and Musolf (2013) state that "it is necessary to better relate the city's characteristics to water-based environmental problems based on comparable methodological approaches" (p.289). Also, land use and occupation, and the quality of sanitary services should be further investigated to establish their influence on water quality and determine the contamination mechanisms, to underpin conservation policies for urban aquifers.

The issue of urban watersheds involves the socio-environmental complexity posed by the occupation and demand for space inherent in city life. The groundwater in these basins, especially in porous aquifers, is significantly integrated with surface waters and therefore is influenced by the lack of sanitation services that are linked to the risks of contamination (PEIXOTO and SILVEIRA, 2017).

Giddens' (2002) hypothesis perceives the risk society as a consequence of reflexivity, where most risks are produced by society itself. According to Porto-Gonçalves (2017), this introduced a new perspective to environmental challenges, as these risks are particularly derived from the interventions of technical-scientific systems. Veyret (2007) proposes that natural risk is the result of the relationship between the natural environment and the negative processes aggravated by human influence through the occupation of territories. Thus this risk is the probability of socio-environmental impact from geoenvironmental characteristics and dynamics. Due to the environment's fragility, the risk, danger, or hazard are enhanced by society's performance/interference in the natural system (PEIXOTO, RODRIGUES, and ALBUQUERQUE, 2019). Therefore, sectorial or generalized environmental risks need to be mapped to minimize and prevent socio-environmental impacts. Mendonça states that:

The attributes used to map risk can be very varied, including hydroclimatological (magnitude and frequency of rainfall, climatic phenomena such as El Niño), hydrological (fluvial hydraulics, or currents generated by waves and tides) and geological-geomorphological (geological substrate, drainage basin morphometry, soil and vegetation cover) factors, in association with anthropic attributes (use and occupation, presence of structures, etc. (MENDONÇA, 2004, p. 142).

Two sets of variables are essential to comprehend groundwater contamination mechanisms. First, the intrinsic fragility of aquifers, including their geological and hydraulic characteristics, and secondly the types of land use and waste generation capable of causing changes in the physical, chemical, bacteriological, or radiological attributes that turn water into a pathogenic substance.

This study understands aquifer vulnerability as an intrinsic fragility of the aquifer. However, the classic term (vulnerability) was selected due to its widespread use in the geosciences. So, aquifer vulnerability methods such as GOD, created by Foster et al. (2006) and DRASTIC, developed by Aller et al., (1987), aim to map the fragility of the aquifer as a function of the dynamics and interactions of natural attributes.

In the case of the urban environment, natural attributes alone do not satisfactorily account for the risk of water contamination. This is because in urban basins there are eminently social-spatial relationships, which include permanent or physical structures for land use and cover, added to the absence of adequate urban services for the population's health. Their effect on water quality should be investigated more thoroughly (PEIXOTO and SILVEIRA, 2017).

There is a gap in the models that map the risk of groundwater contamination in urban areas. The POSH (pollutant origin surcharge hydraulically) model, created by Foster et al. (2006) is based on the potential for contamination and generation of effluent from the contaminating source, taking two variables into account, the coverage of the sewage network and demographic density. POSH has been widely used in urban areas, in association with the GOD method, as observed by Cutrim and Campus (2010), Pinheiro (2015), and Araújo et al., (2017). Also, Meneses et al. (2011) superimposed the DRASTIC model of the physical expansion of the city of João Pessoa over areas of different degrees of aquifer vulnerability. When applying the DRASTIC method in a periurban area in the city of Dakar / Senegal, Faye et al., (2004) identified that the nitrate contamination is greater in the most vulnerable areas, due to the high density of diffuse sources of domestic effluents. 
The principal limitation of the POSH model is that it underrates health variables, as it considers the coverage rate and not access to the service. Peixoto et al. (2017) show that lack of access to a sewage service, even when it is available, is one cause of the high number of septic and rudimentary cesspits in urban areas. The density of these pits has greatly contaminated the groundwater in large cities, especially with nitrate, as evidenced by Barret et al. (1999), Lerner and Yang (2000), Foster and Chilton (2004), Manny, Atmaja and Putra (2016), Peixoto (2017), and Tubal et al. (2017).

The Groundwater Contamination Risk Index - IRCAS, developed by Peixoto and Cavalcante (2019), differs from the above as it considered access not only to sewage collection services but also to garbage collection and the water supply. The latter is an indicator of whether the population is consuming water from underground sources. The model intends to create a synthesis map that is more accurate and allows a better interpretation of the results than overlaying maps. The model supports decision-making for urban aquifer conservation by indicating the areas at highest risk of contamination

It is important to study this reality as the need to understand the society-nature relationship has the potential to explain the socio-spatial segregation of the offer of basic services in cities and groundwater contamination. In this context, this work's objective is to investigate whether the IRCAS is efficient in identifying/predicting aquifer contamination in an urban sub-basin in the city of Fortaleza, Brazil.

\section{MATERIALS AND METHODS}

\section{THE STUDY AREA}

The research was carried out in a $24.5 \mathrm{~km} 2$ urban hydrographic basin in the west of the city of Fortaleza, in the State of Ceará, Northeast Brazil (Figure 1). Fortaleza is the fifth most populous city in Brazil with around 2,669,000 inhabitants (IBGE, 2019). The climate is classified as Dry-Summer Tropical (ALVARES et al, 2014). The annual average temperature is $27^{\circ} \mathrm{C}$, with a maximum of $32^{\circ} \mathrm{C}$, and the rains are concentrated in the interval from February to June, totaling 1,500 mm/year. However, the potential evapotranspiration is $2,300 \mathrm{~mm} /$ year, causing a negative climatic water balance (CEARÁ, 1992).

The lithology of the study area is formed by sedimentary rocks, mostly silt-clay-sandy, representing the Barreiras Formation (BRANDÃO, 1998). The edaphic dunes, present in the Northeast of the area, are formed by sands with homogeneous granulometry, selected and deposited by wind dynamics.
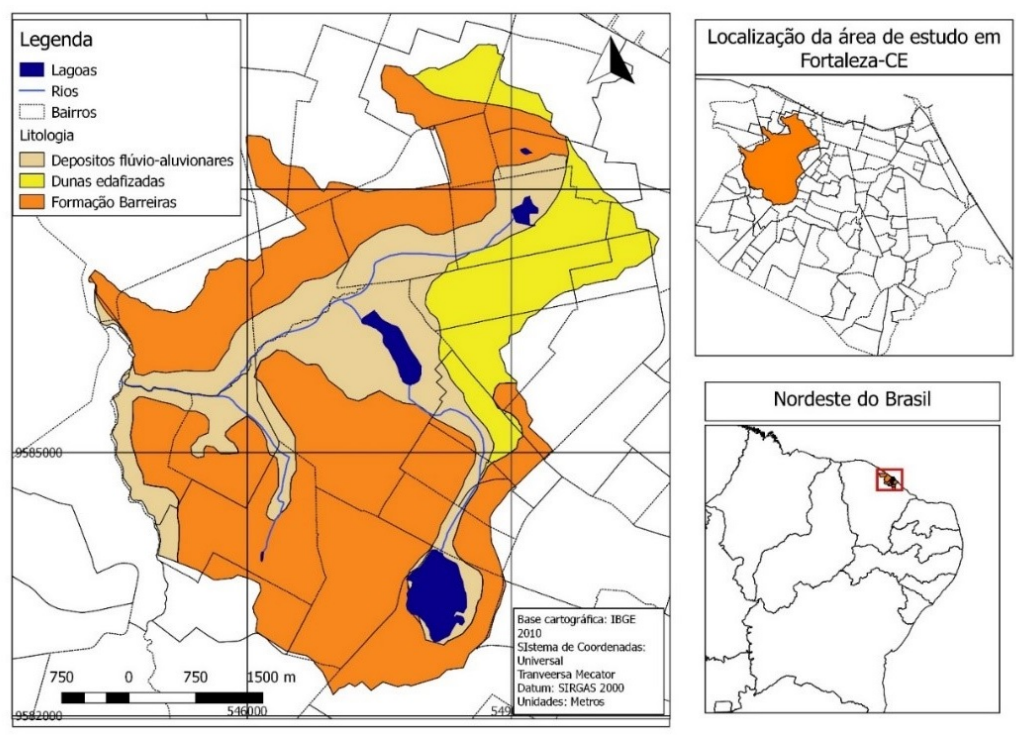

Figure 1 - The lithological units of the study areaThey have the best aquifer potential, providing good flow for wells $\left(5-5 \mathrm{~m}^{3} / \mathrm{h}\right)$ (CAVALCANTE, 1998). 
The Fluvial-alluvial deposits are formed by intercalated layers of silt, sand, and clay, and follow the courses of rivers and lagoons (Figure 1).

\section{GROUNDWATER CONTAMINATION RISK INDEX - IRCAS}

The IRCAS developed by Peixoto and Cavalcante (2019) was designed for use in urban areas, adapting the GOD aquifer vulnerability methodology by Foster et al. (2006), which differentiates susceptibility to water contamination according to the degree of confinement (G), the occurrence of strata and coverage $(\mathrm{O})$, and the depth of the water table (D). These attributes have values that vary from 0 to 1 according to the typologies of the aquifer in question (Figure 2).

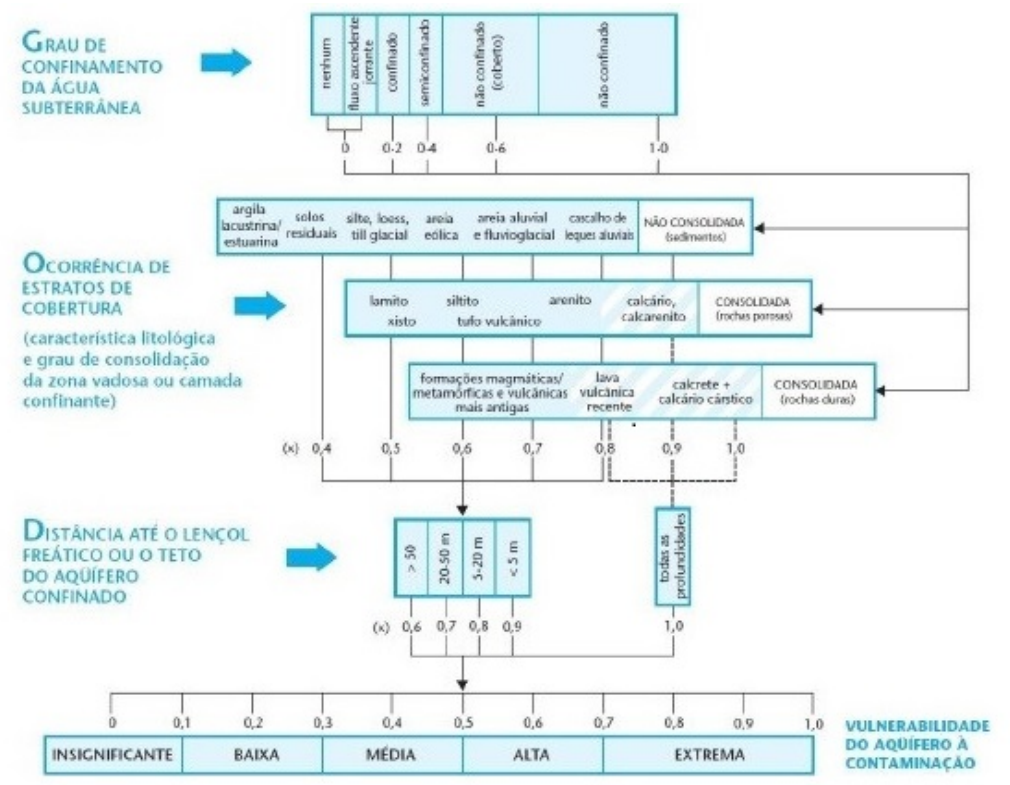

Figure 2 - The conceptual model of the GOD application Source: Foster et al. (2006)

GOD values are integrated according to equation 1 :

$$
G O D=\frac{G \times O \times D}{3}
$$

The aquifer vulnerability values studied here are the same ones employed by Peixoto and Cavalcante (2019) in their study of the aquifers in the municipality of Fortaleza. It was not possible to measure the depth of the static level D in the field as the wells are permanently sealed and do not have openings for the introduction of the measuring sensor.

So, Gomes' (2013) static level measures were used, which showed a phreatic level in the study area that oscillates between 1 and $12 \mathrm{~m}$, so a value of 0.85 was adopted as it is halfway between the classes defined by the GOD conceptual model (Table 1).

\begin{tabular}{lccc}
\hline Unidades Hidrogeológicas & $\begin{array}{c}\text { G -Confinamento da } \\
\text { Água Subterrânea }\end{array}$ & $\begin{array}{c}\text { O - Litologia e } \\
\text { estratigrafia da zona } \\
\text { subsaturada }\end{array}$ & $\begin{array}{c}\text { D - Profundidade do } \\
\text { Nível Freático }\end{array}$ \\
\hline $\begin{array}{l}\text { Depositos Flúvio- } \\
\text { Aluvionares }\end{array}$ & 0,8 & 0,6 & 0,85 \\
\hline Dunas Edafizadas & 0,8 & 0,7 & 0,85 \\
\hline Formação Barreiras & 0,5 & 0,7 & 0,85 \\
\hline
\end{tabular}

Table 1 - values adopted for the application of the GOD aquifer vulnerability 
The interaction between these components resulted in an index-based synthesis map that ranged from 0 to 1 . The composition of the IRCAS adds the Environmental Sanitation Index - ISA by Borges (2008) to the GOD result.

The ISA is based on sub-indices that consider access to water supply, sewage services, and garbage collection. In this study, the ISA has been adapted to vary from 0 to 1 , where the closer a score is to 1 , the worse the local health situation (equation 2).

$$
\text { ISA=IAA+IES+ICL (-1) (2) }
$$

The ISA calculation is based on three sub-indices:

Water Supply Index (IAB) (equation 3);

$$
I A A=\frac{d p p A}{d p p}
$$

In which: IAA: Water Supply Index; dppA: permanent private households supplied by the general network; dpp: permanent private households

Sewage Services Index (HEI) (equation 4):

$$
I E S=\frac{d p p E}{d p p}
$$

In which:

IES: Sewage Services Index; dppE: permanent private households with sewage collected; dpp: permanent private households; fm: minimization factor, which varies according to the proportion of households with sewage according to Borges (2003)

and Garbage Collection Index (ICL) (equation 5):

$$
I C L=\frac{d p p C}{d p p}
$$

In which: ICL: Garbage Collection Index; dppC: permanent private households with garbage collection;dpp: permanent private households.

The IRCAS quantifies the risk of groundwater contamination taking into account the aquifer's susceptibility as represented by the GOD and the sanitary conditions calculated by the ISA, consequently, according to the equation developed by Peixoto and Cavalcante (2019), the integration between these two models is as follows, (equation 6):

$$
\operatorname{IRCAS}=\frac{\mathrm{GOD}+(1-\mathrm{ISA})}{2}
$$

The values from 0 to 1 assess the degree of risk of groundwater contamination; the closer to 1 the greater the risk. Here, the degrees of risk were positioned according to natural breaks, between $0.200 \geq$ 0.302 (low), $0.302 \geq 0.351$ (medium) and $0.351 \geq 0.479$ (high). 


\section{THE INTEGRATION OF THE GEOGRAPHIC INFORMATION SYSTEM DATA AND WATER QUALITY}

All sanitary parameters were obtained from data from the census conducted in 2010 by the Brazilian Institute of Geography and Statistics - IBGE (2011), which were aggregated into census sectors, using the Quantum Gis 2.18 software to produce a georeferenced database to support the nitrate and nitrite kriging process.

Also, algebra mapping was carried out using the calculator in the software's attributes table.

The water quality parameters were analyzed at the Environmental Geochemistry Laboratory of the Department of Geology of the Federal University of Ceará - UFC, on the day they were collected in both the rainy season (03/Jul 2018) and the dry season (18/ Nov 2018). The samples were collected utilizing the pumping mechanism of the well itself, following the hygiene criteria, and then the samples were conserved in polypropylene bottles and stored in a thermal box with ice.

Samples from 30 wells were analyzed in the rainy season, and the process was repeated for the same 30 wells in the dry season, for the parameters: bicarbonate-HCO3-; chloride-Cl-; sulfate-SO42-; potassium-K+; calcium-Ca2+; magnesium- $\mathrm{Mg}^{2+}, \quad \mathrm{pH}$, alkalinity, electrical conductivity - CE; ammonium-NH3+; ammoniacal nitrogen-N-NH 4+; nitrite-NO2-; nitrate-N-NO3-; iron-Fe2+; silica-Si2+; fluoride-Fl-; turbidity; water hardness, total dissolved solids-STD, all according to the standard methodologies of American Public Hearth Association - APHA (2012).

The collection of N-NH4+ was carried out by adding a compound between the hypochlorite and phenol reaction, used to preserve the sample's properties for analysis. The $\mathrm{pH}$, STD, and electrical conductivity parameters were determined using a multiparameter meter (Thermo Scientific Orion and Star A329 Portable model).

The Bartlett sphericity test was performed to test the hypothesis that the variables were not correlated with the population, producing an identity matrix in which the correlation would not be appropriate for factor analysis. Therefore, this test's result must be equal to 0 to negate the hypothesis and consider the data adequate for the intended analysis. Next, the Kaiser-Meyer-Olkin (KMO) data adequacy test was done to identify the data's adequacy for factor analysis. According to Hair et al., (1995) values between 0.5 and 1 are acceptable.

Both of these analyzes were performed using the SPSS statistics 2.0 software. The results show values of 0 for both periods, and the KMO adequacy test obtained a result of 0.661 for the rainy period and 0.625 for the dry period. Based on the best $\mathrm{KMO}$ results, the following variables were chosen to apply the principal component analysis: $\mathrm{ACP}$ : $\mathrm{HCO}_{-}-\mathrm{Cl}_{-} ; \mathrm{SO}_{2}-; \mathrm{K}+; \mathrm{Ca}^{2+} ; \mathrm{Mg}^{2+}, \quad \mathrm{pH}, \quad$ alkalinity; $\mathrm{N}-\mathrm{NH} 4+; \mathrm{NO}_{2}-; \mathrm{N}-\mathrm{NO} 3-; \mathrm{Fe}^{2+}$; Fl; turbidity; water hardness and STD.

The principal component analysis - ACP was applied using the Andad 2.0 software, allowing associations between parameters to be identified, especially for $\mathrm{NO}_{2}$ - and $\mathrm{N}^{\mathrm{NO}}$, and the other physical and chemical parameters. The ACP used two factorial plans, the first consisted of $51.3 \%$ variance and the second $32.4 \%$, the total of which was an acceptable value (above $80 \%$ ) for the analysis.

Geostatistics was carried out based on the kriging interpolation model with nitrate and nitrite values, as these showed concentrations above the WHO (2011) maximum allowed value of $10 \mathrm{mg} / \mathrm{L}$ for nitrate and $1 \mathrm{mg} / \mathrm{L}$ for nitrite.

\section{THE EFFICIENCY TEST}

The efficiency of the IRCAS model was tested to identify and predict the relationship between groundwater contamination of N-NO3- by indicating the degrees of contamination risk. To this end, the ANOVA variance analysis was employed to classify those wells in the classes defined by IRCAS as having a high, medium, and low degree of risk of contamination.

To identify the difference between the classes, the Tukey test was used, which indicated the greatest differences between them and the most distinct classes. 


\section{RESULTS AND DISCUSSION}

\section{GROUNDWATER CONTAMINATION RISK INDEX - IRCAS}

Although it considers vulnerability, the model applied here aims to identify the risk of contamination, principally by domestic effluents. The study area is essentially residential, with some commercial sectors along most important avenues. Thus, the local land use and occupation make the sanitary quality of dwellings one of the main variables when considering the potential sources of groundwater contamination. The GOD spatial variables are intrinsic to the aquifer, so the accessibility of the contaminating medium to the water table is also important for understanding the contamination mechanisms (Figure 3).

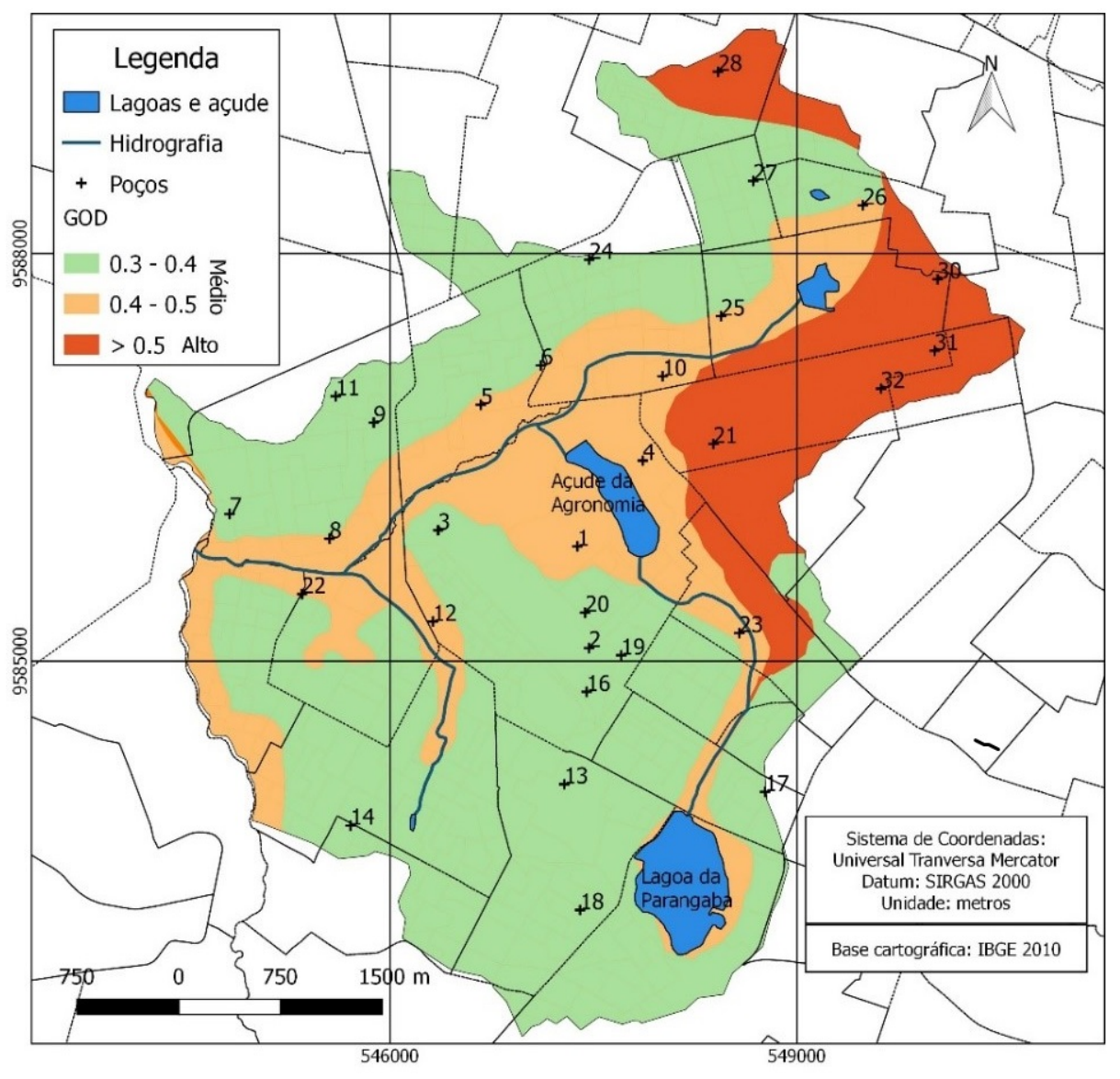

Figure 3 - The GOD aquifer vulnerability map

The Edaphic Dunes are part of the Dunas Aquifer System - SAD, which has a good aquifer potential, especially due to its high renewability, however, the permoporosity that promotes rapid infiltration also makes it vulnerable. This unit has values above 0.5 , so it has a high level of susceptibility, whereas in general, the Alluvions and the Barreiras Formation, have a horizontal or semi-horizontal layering, which provides greater protection against infiltration by effluents, thus they have average risk, between $0.3 \geq 0.5$.

The ISA diagnosed different situations of access to basic sanitation services. The arrangement into census tracts allowed the data to be refined, and although these sectors have different sizes, their values were normalized according to their respective number of households (Figure 4). 


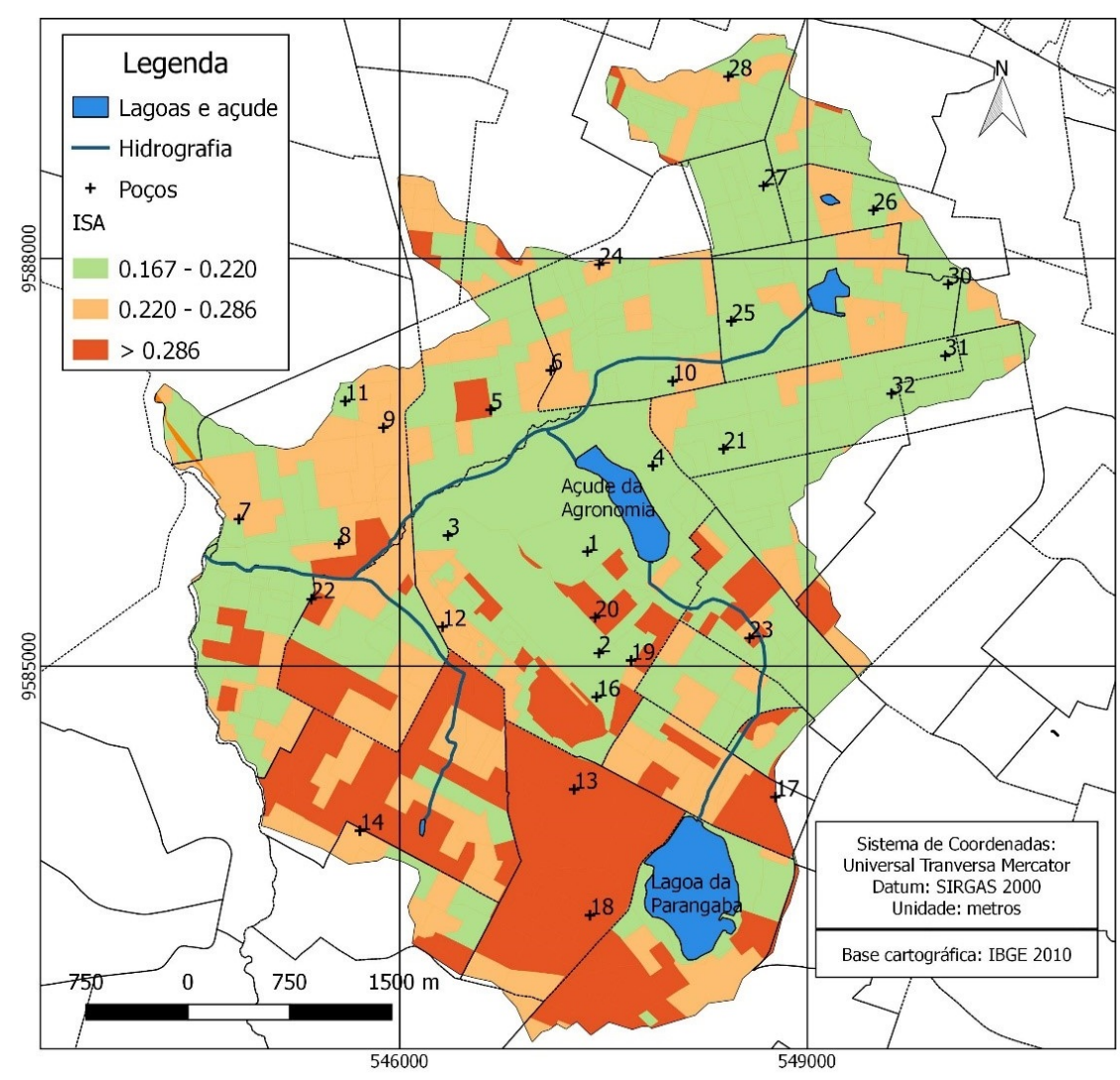

Figure 4 - The Environmental Sanitation Index Map

The study area has efficient water supply and garbage collection services, both had access rates above 0.85 for all sectors. Therefore, the biggest health problem is access to sewage services. Although the entire area has a sewage collection system, in some sectors less than $25 \%$ of the housing has access to it, especially in the southern part of the area

.It is evident that two widespread and distinct situations of access to basic sanitation exist in the study area, therefore the research characterizes a transition from north to south, from a central area that is more valued from the urbanist point of view, to an area with more peripheral characteristics, described as peri-urban by Kurian and MacCarney (2010). 


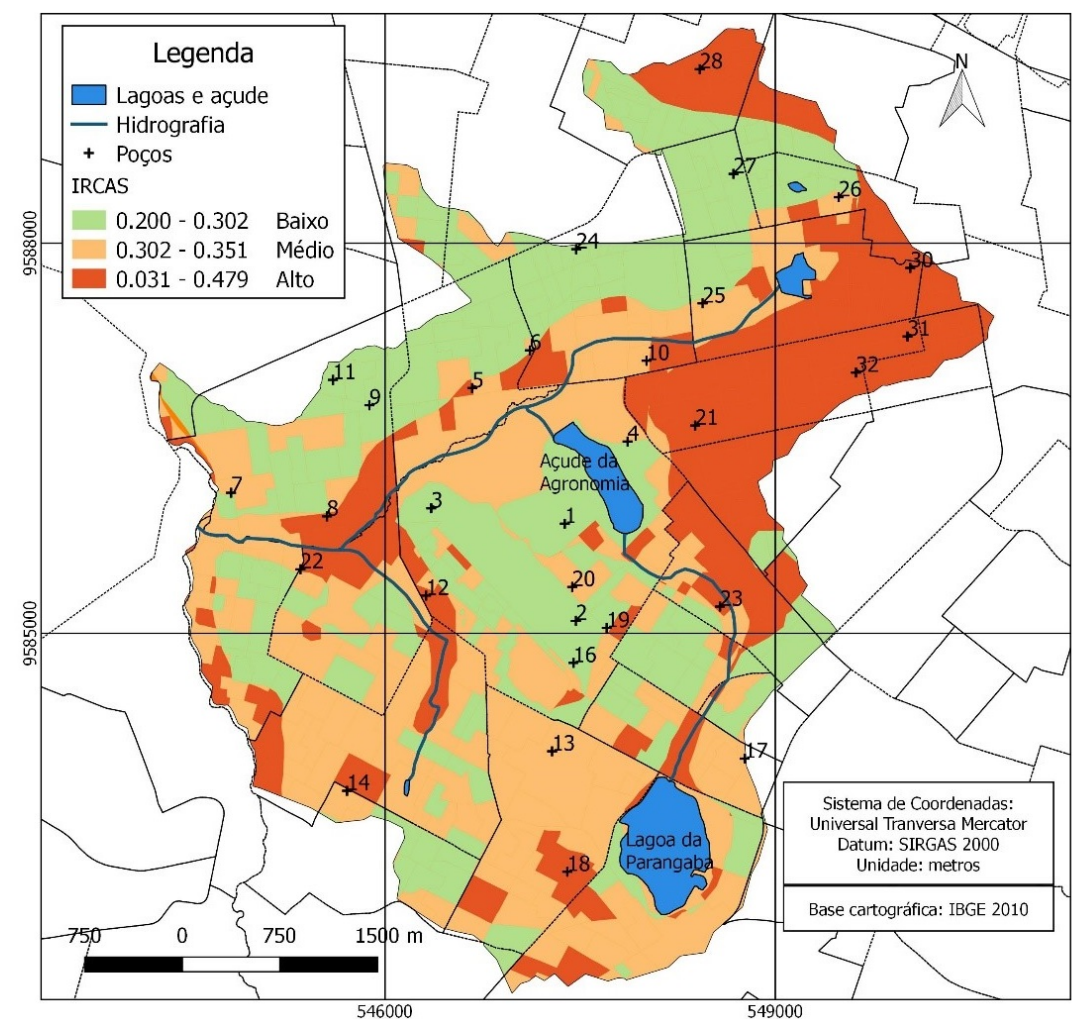

Figure 5 - The Contamination risk map

The IRCAS shows that the greatest possibility of contamination occurs in a dispersed way, mainly due to the low ISA values of several of the census sectors in the southern portion. In general, there is also high risk in the Northeast part of the area, due to the greater SAD aquifer vulnerability (Figure 5).

\section{WATER CONTAMINATION AND THE CALIBRATION OF THE IRCAS MODEL}

The principal component analysis - ACP showed few differences between the dry and wet seasons. There is an association between all the main ions in the wet period, as also verified by Zang et al. (2015), except for bicarbonate (HCO-), which is associated with alkalinity and $\mathrm{pH}$.

This behavior was also evidenced in the dry period, but the sulfate was displaced and was not associated with any ions. In both periods there was an inverse correlation between $\mathrm{pH}$ and NO3- as seen in ACP Factor 2 (F2) (Figures 6 and 7).

The decrease in $\mathrm{pH}$ has a biogeochemical relationship with the oxidation of organic matter and nitrate contamination (HEM, 1959). Wilhelm et al. (1996) and Liu et al. (2013) suggest that groundwater acidification may be caused by the oxidation of NO2- to NO3-. Therefore, in this case, the water also has high concentrations of NO3-.

Nitrate is the most problematic parameter studied in the area. Of the water samples from wells in the wet and dry season, 16 and 14, respectively, exceed the regulatory limits of the WHO (2011). In other words, $53 \%$ of samples in the rainy season and $46 \%$ in the dry season were found to be contaminated; since nitrate is an indicator of anthropogenic contamination, several bacteriological pathogens may also be present in this water.

Nitrate contamination from water sources harms the water supply because its high persistence in its ionic form makes conventional treatment unfeasible, thus increasing the operational and environmental treatment costs. In Natal - RN, the process of nitrate contamination of groundwater has been at an advanced stage for more than two decades, due to the sanitation system adopted with the local disposal of effluents via cesspits and sinks. The public supply company's strategy to maintain acceptable water quality uses the dilution process (MELO et al., 2010) 


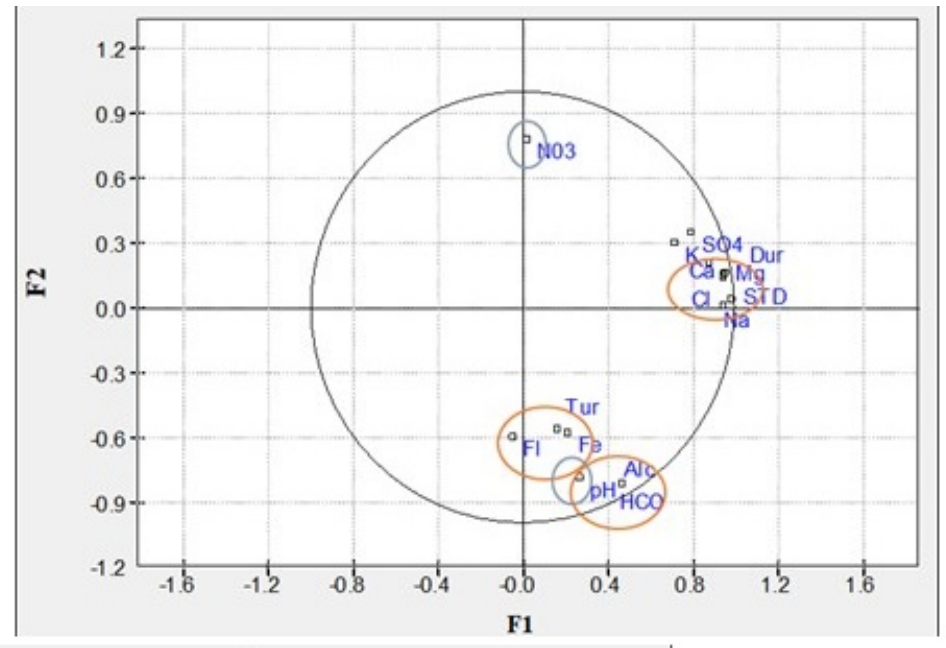

Figure 6 - ACP of well water quality in the rainy season. Caption: Tur - turbidity; Fl - fluoride; Fe - iron; Alk - alkalinity; K - potassium; Ca - calcium; Mg - magnesium; Dur - hardness; Na - sodium; NO3 nitrate; SO4 -sulfate; STD - total dissolved solids.

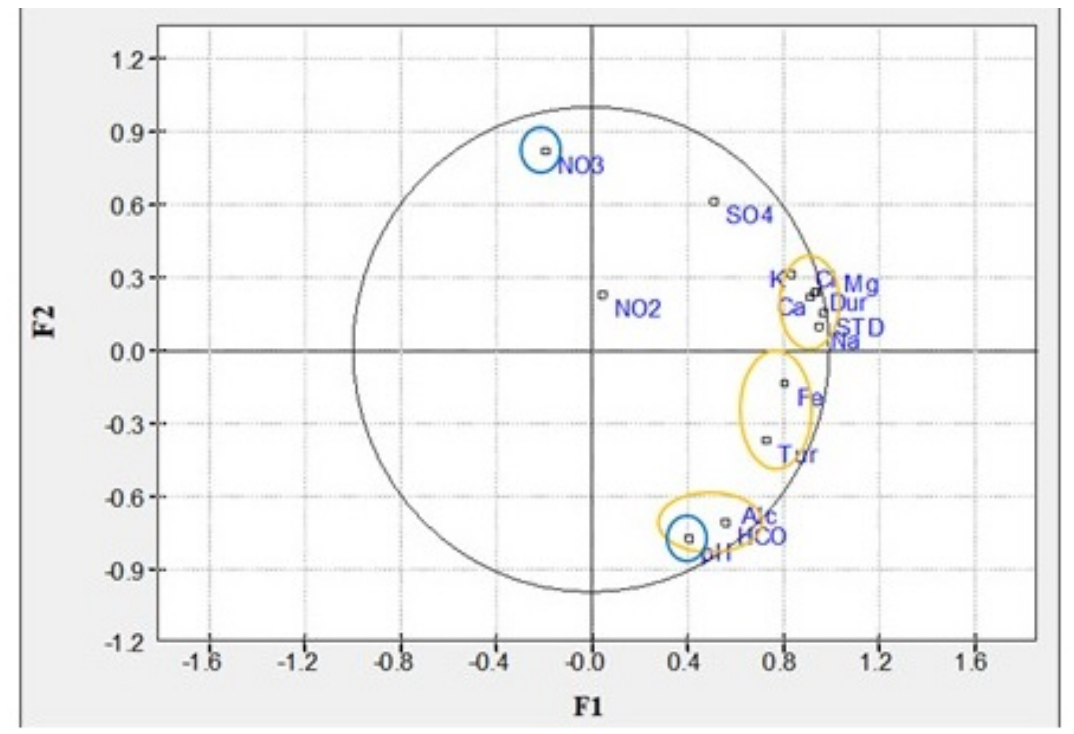

Figure 7 - ACP of well water quality in the dry period. Caption: Tur - turbidity; Fl - fluoride; Fe - iron; Alk - alkalinity; K - potassium; Ca - calcium; Mg - magnesium; Dur - hardness; Na - sodium; NO3 nitrate; SO4 -sulfate; STD - total dissolved solids

In the wet period, the average nitrate concentration is higher than in the dry period. The refill performance may be related to contamination. In the dry period, concentrations reached the highest value $(35 \mathrm{mg} / \mathrm{L})$, but in a more concentrated and localized manner. This indicates that the entry of contamination from domestic effluents is higher than in the wet period.

The most widespread contamination was observed in the rainy season and occurred in the southeast and south, with concentrations above $13.5 \mathrm{mg} / \mathrm{L}$. A similar situation also occurred in the center-north, with values between 17.3 and $33.2 \mathrm{mg} / \mathrm{L}$ in the water samples from wells 21,25 and 27 (Figure 8). 


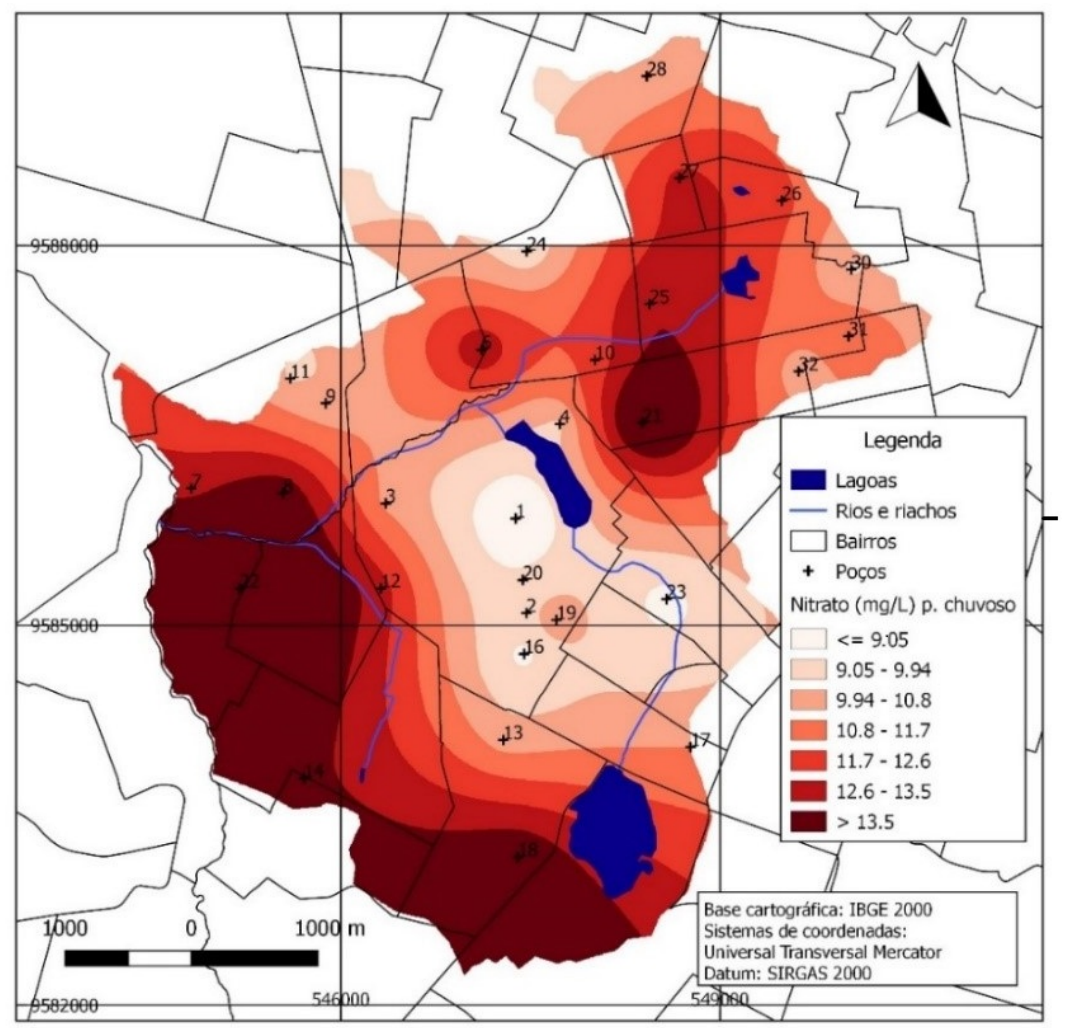

Figure 8 - Zoning of N-NO3 - concentrations in the rainy season

In the dry season, the main nitrate concentration occurred in the northeastern section, where well 21 had a water sample concentration of $35.6 \mathrm{mg} / \mathrm{L}$ and wells 25,26 , and 31 had water samples between 16 and $28.1 \mathrm{mg} / \mathrm{L}$ nitrate. High concentrations (14.2 and $18.2 \mathrm{mg} / \mathrm{L}$ ) also occurred at the southern end of the area, in wells 17 and 18, respectively (Figure 9).

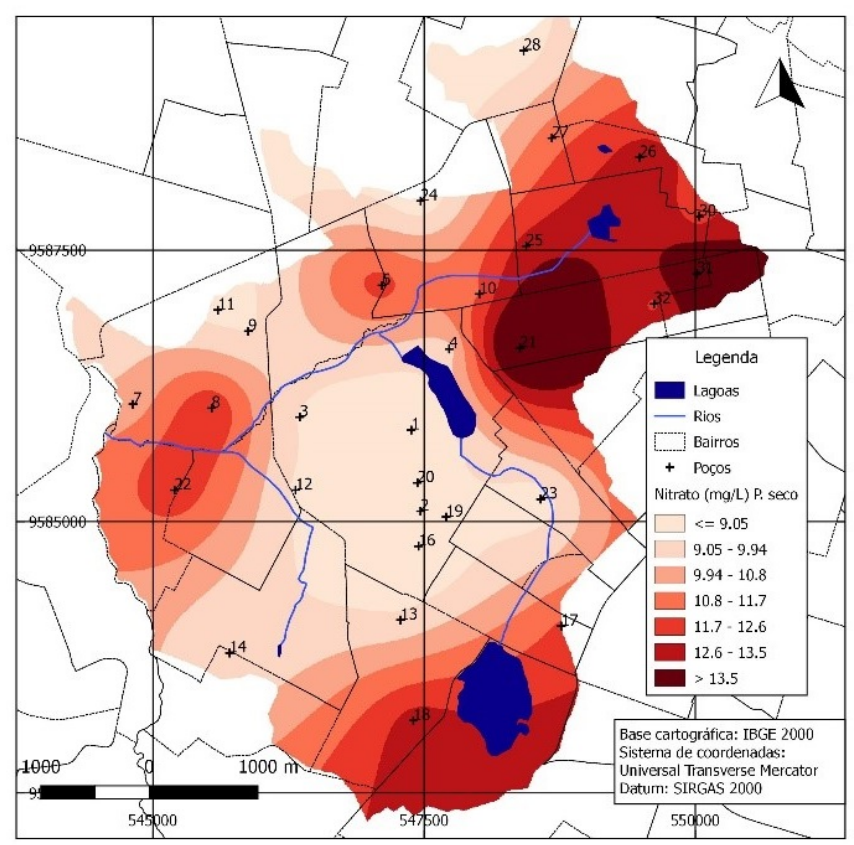

Figure 9 - Zoning of N-NO3 - concentrations in the dry period 
The more deficient the sanitation, the greater the risk of groundwater contamination. This is probably due to the high density of septic tanks and rudimentary cesspits, especially in households that do not have a connection to the sewage network. Similar situations are observed in studies such as Matiatos (2016), which found that industrial and urban areas are mainly characterized by enriched values of $\delta 15 \mathrm{~N}-\mathrm{NO} 3$ - indicating that septic and industrial waste were probably the sources of nitrate contamination. In a study in the Peral River Delta in southern China, Zhang et al. (2015) also showed that domestic and industrial wastewater were the main sources of groundwater contamination.

High volumes of effluents are more mobile during the rainy season, when water infiltration takes the contaminants to the saturated zone, thus reaching the water table. In the area of greatest aquifer vulnerability, with a high SAD permeability (20\%) (CAVALCANTE, 1998), the effluents can percolate the porous material more quickly. Also, nitrite concentrations above $0.08 \mathrm{mg} / \mathrm{L}$ are considered a recent contamination. The land use and cover may also have influenced this, for example, through an excessive waterproofing of the soil that contributes to the loss of water quality and quantity infiltrated from the runoff. A study in Madison, USA by Burant et al. (2018), showed that some organic contaminants provided information about the similarities and differences between organic contaminants in urban runoff derived from different land uses. Tubal et al.'s (2016) study of urban aquifer recharges in Barcelona, Spain, evidenced the efficiency of data on water use, population density, per capita allocation, and land use in the absence of more direct recharge data.

Nitrite is in the intermediate position in the nitrogen circle, and it is important in the understanding of contamination mechanisms because its presence can identify recent contamination. Trace concentrations of nitrite were detected in $40 \%$ of the wells in both samples (rainy and dry). The values were between 0.02 and $0.3 \mathrm{mg} / \mathrm{L}$. However, in the water sample from well 31, the concentration was significant $(1.1 \mathrm{mg} / \mathrm{L})$, given that it exceeded the limit for potability according to the Ministry of Health Consolidation Ordinance $\mathrm{N}^{\circ} 5$ of 2017 (Figure 10).

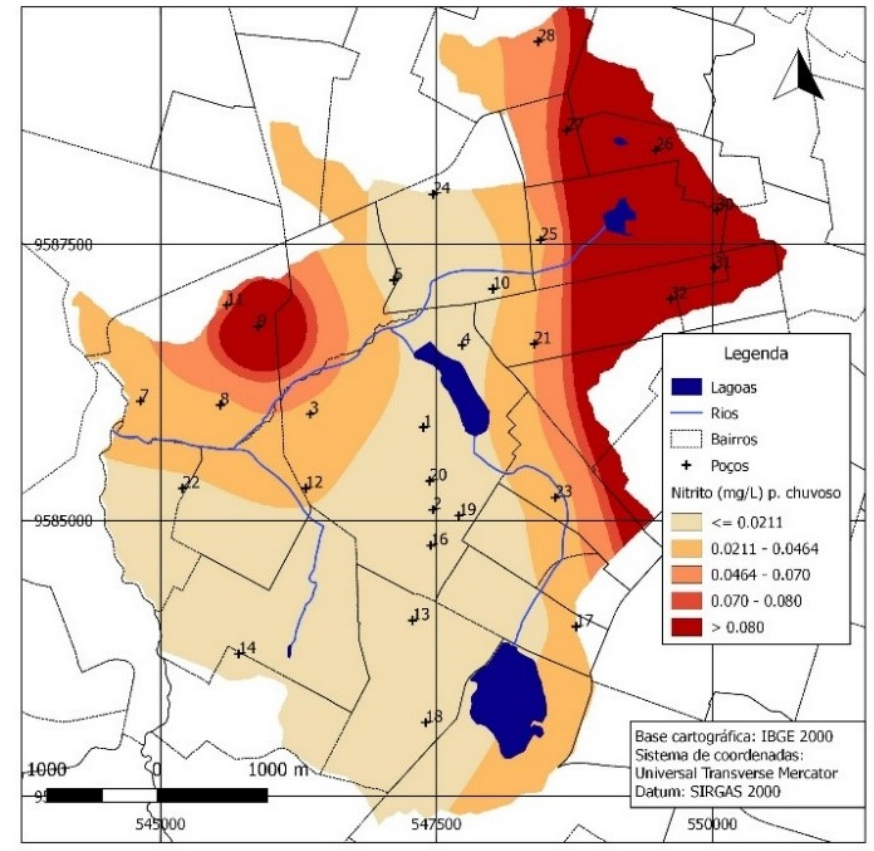

Figure 10 - Zoning of nitrite concentrations in the rainy season

Despite the low values, water samples from the wells reveal higher concentrations of nitrite in the rainy season, including values of $0.3 \mathrm{mg} / \mathrm{L}$ in the waters of wells 9 and 11 in the rainy season (Figure-10). In the dry period, nitrite was detected only in the extreme northeast (Figure 11) indicating that in the sector where wells 9 and 11 are located, infiltration acts as a process conducting contaminants from domestic effluents to the groundwater. Most of the nitrite values are associated with a zone of high contamination risk defined by the IRCAS. It is also considered that the aquifer SAD vulnerability is a 
stronger determinant for nitrite contamination than the sanitary quality of the census sectors.

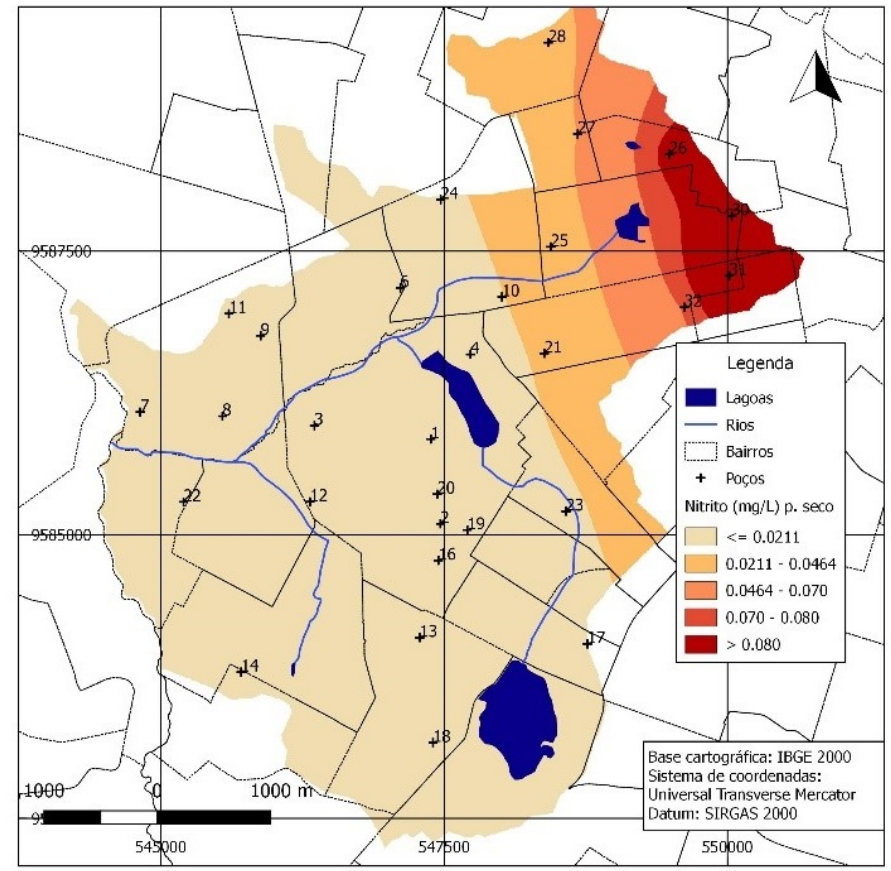

Figure 11 - Zoning of nitrite concentrations in the dry period

\section{ANALYSIS OF THE MODEL'S EFFICIENCY}

The variance analysis identified important seasonal characteristics regarding nitrate contamination. In the rainy season, the F-value indicates the significance of the test, as the probability of value $\mathrm{p}$ is less than $5 \%$, rejecting the null hypothesis, therefore there must be at least a significant contrast between the types of risk applied. The ratio between the sum of the product squares and the total was 0.608 , showing that the IRCAS explains $61 \%$ of the variance behavior for nitrate values in the rainy season (Table 2). Thus, the identification and prediction of nitrate contamination using this methodology can be considered efficient, considering the complexity of groundwater contamination mechanisms in the urban environment. The Tukey test identified that the difference between medium and low risk is greater than that of high to medium risk (Table 3)

\begin{tabular}{lrrr}
\hline $\begin{array}{l}\text { Causas da } \\
\text { variação }\end{array}$ & $\begin{array}{r}\text { Soma dos } \\
\text { quadrados }\end{array}$ & $\begin{array}{r}\text { Valor de } \\
\mathrm{F}\end{array}$ & Valor de p \\
\hline Entre grupos & 1094,17 & 16,28 & $5,37 \mathrm{E}-05$ \\
\hline Resíduos & 705,524 & - & - \\
\hline Total: & 1799,69 & - & - \\
\hline
\end{tabular}

Table 2 - Anova for N-NO3 - values in the rainy season

\begin{tabular}{lrrr}
\hline & Alto & Médio & Baixo \\
\hline Alto & - & 0,006621 & $3,67 \mathrm{E}-05$ \\
\hline Médio & 4,868 & - & 0,09068 \\
\hline Baixo & 8,009 & 3,141 & - \\
\hline
\end{tabular}

Table 3 - Tukey test for Anova performed during the rainy season 
In the dry period, the F-value was significant, and the P-value of probability was less than $5 \%$. Thus, the null hypothesis was rejected and the application of ANOVA to the proposed degrees of risk is considered statistically significant. The ratio of the sums of squares between groups and the total was 0.539. This means that IRCAS explains $54 \%$ of the variances for nitrate values. The Tukey test also identified less variation between upper and middle classes than in the rainy season. The greatest distinction between risk classes for the dry period remains high to medium risk.

\begin{tabular}{lrrrr}
\hline $\begin{array}{l}\text { Causas da } \\
\text { variação }\end{array}$ & $\begin{array}{l}\text { Soma dos } \\
\text { quadrados }\end{array}$ & $\begin{array}{l}\text { Valor de } \\
\text { F }\end{array}$ & $\begin{array}{l}\text { Valor de } \\
\text { p }\end{array}$ \\
\hline Entre grupos & 1047,6 & 12,32 & 0,000289 \\
\hline Resíduos: & 893,017 & - & - \\
\hline Total: & 1940,62 & - & - \\
\hline
\end{tabular}

Table 4 - Anova for N-NO3 - values in the dry season

\begin{tabular}{lrrr}
\hline & Alto & Médio & Baixo \\
\hline Alto & - & 0,04082 & 0,000187 \\
\hline Médio & 3,703 & - & 0,07161 \\
\hline Baixo & 7,016 & 3,313 & - \\
\hline
\end{tabular}

Table 5 - Tukey test for Anova performed during the dry season

\section{CONCLUSION}

The census sectors classified using the ISA indicated a lower quality of sanitation in the southern part of the study area. Nevertheless, the IRCAS pointed out a larger continuous risk area in the northeast of the area, due to the SAD aquifer vulnerability. Most medium and high-risk occurrences in the south of the study area resulted from the low environmental quality diagnosed by the ISA.

The ACP showed a common relationship between the main ions, and this occurred similarly in the two seasons studied. The negative correlation between nitrate and $\mathrm{pH}$ reveals an oxidation transformation mechanism of NO3- to N2. Also, the nitrate contamination in 53\% and $47 \%$ of samples in the wet and dry period, respectively, indicates that this is the most frequent type of contamination in the area. The aquifer studied is characterized as free with rapid oxidation of the nitrogen compound and therefore low concentrations of NO2- and high concentrations of N-NO 3 - were observed.

The IRCAS' efficiency was measured by ANOVA, the nitrate data from the water collected from the wells had values of 0.608 and 0.539 for the rainy and dry periods, respectively. Thus, the effectiveness was defined as $61 \%$ for the rainy season and $54 \%$ for the dry season. These values were considered significant, particularly regarding the rainy season, given the high complexity of the groundwater contamination mechanism, and the lack of detailed knowledge of the local hydrogeology. Despite this, the model overestimated the risk, as the most widespread contamination occurred in the rainy season, also the IRCAS' most efficient aspect.

The greatest differences between the classes defined by the IRCAS occurred between medium and low risk, which denotes that the larger classes have greater proximity due to a certain confusion between the nitrate data and the classes defined by the model. The newly created IRCAS still needs to be applied and adjusted to increase its efficiency in predicting water contamination. Nonetheless, the results are satisfactory, filling a gap left by the absence of risk methodologies for groundwater contamination in the urban environment. 


\section{REFERENCIAS}

ALLER, L., BENNETT, T., LEHR, J.H., PETTY, R., HACKETT, G. DRASTIC: A standardized system for evaluating groundwater pollution in potential using hydrogeologic settings. EPA1600 2- 87035, 1987.

ALVARES, A. C.; STAPE, J. L.; SENTElhaS, P. C.; GOlÇALVES, M. L. J.; SPAROVEK, G. (2014) Koppen's climate classification map for Brazil. Meteorologische Zeitschrift, 22, 6, 2014.711-728.

AMERICAN PUBLIC HEALTH ASSOCIATION-APHA, Standard methods for the examination of water andwastewater. ed. 22. American Public Health Association, Washington, DC, 2012.

(PDF) Influence of Land Use and Sanitation Issues on Water Quality of an Urban Aquifer. Available from:

https://www.researchgate.net/publication/338617355_Influence_of_Land_Use_and_Sanitation_Issues_o n_Water_Quality_of_an_Urban_Aquifer[accessed Apr 08 2020].

ARAÚJO, K. V.; CAVALCANTE, I. N.; OLIVEIRA, R. M.; PEIXOTO, F. S.; LIMA NETO, I. O. Vulnerabilidade natural e perigo de contaminação do Sistema Aquífero Dunas na região norte do Município de Aquiraz, Ceará. Revista do Instituto Geológico, v. 38, n. 2, p. 37 - 48, 2017. http://dx.doi.org/10.5935/0100-929X.20170008.

BARRET, M. H.; HISCOCK, K. M.; DEPLEY, S.; LERNER, D. N.; TELLAN, J. H.; FRENCH, M. J. Maker Spicies For Identifying Urban Groundwater Recharge Sources: a review and case study in Nottingham, UK. Water Resource, [s.1.] v. 33, n. 14, p. 3083 - 3097, ago. 1999.

BORGES, U. N. Análises de riscos potenciais de degradação ambiental em bacias hidrográficas urbanas com o apoio de tecnologias de baixo custo. Dissertação (Mestrado). Recife: Cento de Tecnologia e Geociências - UFPE, 2008.

BRANDÃO, R. L. Diagnóstico geoambiental e os principais problemas de ocupação do meio físico da Região Metropolitana de Fortaleza. Sistema de Informações para Gestão e Administração Territorial da Região Metropolitana de Fortaleza -Projeto SINFOR: Fortaleza: CPRM. 1998. p. 88.

BURANT, A.; SELBIG, W.; FURLONG, E. T.; HIGGINS, C. P. (2018) Trace organic contaminants in urban runoff: Associations with urban land-use, Environmental Pollution n. 242, p. 2068-2077. 2018. doi: https://doi.org/10.1016/j.envpol.2018.06.066

CAVALCANTE, I.N. Fundamentos Hidrogeológicos para a Gestão Integrada de Recursos Hídricos na Região Metropolitana de Fortaleza, Estado do Ceará. 1998. 153f. Tese (Doutorado em Hidrogeologia) -Instituto de Geociências, Universidade de São Paulo. São Paulo. 1998.

CEARÁ. Plano Estadual de Recursos Hídricos. Secretaria dos Recursos Hídricos. Fortaleza: Atlas, 1992. v.1.

CUTRIM, A. O. CAMPOS, J. E. G. Aplicação dos Métodos Drastic e Posh para a Determinação da Vulnerabilidade e Perigo à Contaminação do Aquífero Furnas na Cidade de Rondonópolis-MT. Revista Brasileira de Recursos Hídricos, Porto Alegre, v. 15, n. 2, p. 127 - 142, 2010.

FAYE, S. C.; FAYE, S.; WOHNLICH, S.; GAYE, C. B. Na assessment of the risk associated with urban development in the Thiaroye area (Senegal). Environmental Geology, 2004, n. 45, p. 312 - 322, 2004.

FOSTER, S. S. D. \& CHILTON, P. J. Dowmstream of downtown: urban wastewater as groundwater recharge. Hydrogeology Journal, [s.1.] v.12, p.115-120, mai. 2004.

FOSTER, S., HIRATA, R., GOMES, D., D’EliA, M., PARIS, M. Proteção da Qualidade da Água Subterrânea: um guia para empresas de abastecimento de água, órgãos municipais e agências ambientais. Washington, D.C.: Banco Mundial. 2006, Disponível em: http://siteresources.worldbank.org/INTWRD/Resources/3364861175813625542/GroundwaterQualityPr 
otectionGuide_Portugese.pdf.

INSTITUTO BRASILEIRO DE GEOGRAFIA E ESTATÍSTICA, IBGE cidades: Fortaleza, população estimada. link: https://cidades.ibge.gov.br/brasil/ce/fortaleza/panorama, 2019. acesso em 08 de abril de 2020 .

INSTITUTO BRASILEIRO DE GEOGRAFIA E ESTATÍSTICA, IBGE, Censo demográfico 2010. Características da população e dos domicílios: resultados do universo. Rio de Janeiro: IBGE, 2011. Acompanha 1 CD-ROM. Disponível em: . Acesso em: mar. 2013.

GIDDENS, A. Modernidade e identidade. Rio de Janeiro: Zahar Ed., 2002.

GOMES, M. C. R. Análise situacional qualitativa sobre as águas subterrâneas de Fortaleza, Ceará Brasil como subsídio a gestão dos recursos hídricos. Tese (Doutorado), Centro de Ciências, Fortaleza UFC. 2013

HEM, J. D. Study and Interpretation of the Chemical Characteristics of Natural Water. U.S.G.S. Water Supply Paper, 1473. 1. ed. 1959. 269 p.

HAIR J.F. JR., ANDERSON R.E., TATHAM R.L. BLACK W.C. Multivariate Data Analysis, 3rd ed. New York: Macmillan, 1995.

KURIAN, M.; MCCARNEY, P. Periurban water and sanitation service. Springer, 2010.

LERNER, D. N.; YANG, Y. Quantifying recharge at the city scale using multiple environmental tracers. Annals...Conference held at Liège, Belgium. IAHS v. 262, 2000.

LIU, C. W.; WANG, Y.; B. JANG, C. S. Probability-based nitrate contamination map of groundwater in Kinmen. Environmental Monit. Asses. n. 185, p. 10147 -10156, 2013.

MANNY, L.; ATMAJA, R. R. S.; PUTRA, D. P. E. Groundwater level changes in shallow aquifer of Yogyaarta City, Indonesia: Distribuition and Causes. Journal of Applied Geology, [s.l.], v.1, n. 2, p. 89-99, feb. 2016.

MATIATOS, I. Nitrate source identification in groundwater of multiple land-use areas by combining isotopes and multivariate statistical analysis: A case study of Asotopos basin (Central Greece), Science of the Total Environment n. 541, p. 802-814, 2016. doi: http://dx.doi.org/10.1016/j.scitotenv.2015.09.134

MELO, J. G.; VASCONCELOS, M. B.; OLIVEIRA, J; MORAIS, S. D. O.; CELESTINO JÚNIOR, P.; ALVES, R. S. Atualização de conhecimentos sobre a hidrogeologia e contaminação das águas subterrâneas da zona norte de natal, RN., In: XVI Congresso Brasileiro de Águas Subterrâneas, São Luiz, MA, Brasil. 2010.

MENDONÇA, F. Riscos, vulnerabilidade e abordagem socioambiental urbana: uma reflexão a partir da RMC e de Curitiba. Desenvolvimento e Meio Ambiente, Curitiba, v. 10, n. 2, p. 139-148, 2004.

MENEZES, L. F. S. FIGUEIREDO, E. C. T. P.; RAFAEL, R. A. Evolução urbana e vulnerabilidade dos aquíferos superiores no Município de João Pessoa - PB. Revista Brasileira de Cartografia, v. 63, n. 2, p. $267-280,2011$.

MINISTÉRIO DA SAÚDE, Portaria de Consolidação $n^{\circ} 5$ de 28 de setembro de 2017. Consolidação das normas sobre as ações e os serviços de saúde do Sistema Único de Saúde. Disponível em: http://bvsms.saude.gov.br/bvs/saudelegis/gm/2017/prc0005_03_10_2017.html.

PEIXOTO, F. S. Efeitos do uso e ocupação do solo sobre as águas subterrâneas: contaminação da água subterrânea por nitrato em sub-bacia urbana na cidade de Fortaleza/Brasil. 1. ed. Baue Bassin: Omni Scriptium Publishing Group, 2017. v. 1. 125p

PEIXOTO, F. S.; CAVALCANTE, I. N. SILVEIRA, R. N. M. C.; BESERRA, F. R. S. O Sistema de Informação Geográfica (SIG) aplicado ao Abastecimento Hídrico e Esgotamento Sanitário. Revista do Departamento de Geografia USP, São Paulo, Edição Especial XVII SBGFA, p. 20 - 28. 
2017.doi:https://doi.org/10.11606/rdg.v0ispe.132599

PEIXOTO, F. S.; RODRIGUES, J. P. B.; ALBUQUERQUE, P. I. M. Gestão integrada dos recursos hídricos e a problemática das inundações urbanas. Geografia, Londrina, v. 28, n. 1. p. 187 -206, 2019.

PEIXOTO, F. S.; SILVEIRA, R. N. M. C. Bacia hidrográfica: tendências e perspectivas da aplicabilidade no meio urbano. Revista Brasileira de Geografia Física, Recife, v. 10, n. 3, p. 840 - 853 , 2017. https://doi.org/10.5935/1984-2295.20170058.

PEIXOTO, F., \& CAVALCANTE, I. Vulnerabilidade aquífera e risco de contaminação da água subterrânea em meio urbano. Geologia USP, Série Científica, São Paulo, v.19, n. 2, p. 29-40. 2019, doi: https://doi.org/10.11606/issn.2316-9095.v19-142384.

PINHEIRO, R. J. B.; RAUBER, A. C. C.; NUMMER, A. V.; SILVA, J. L. S. Aplicação dos métodos GOD e POSH para determinação da vulnerabilidade e perigo à contaminação dos aquíferos na cidade de Santa Maria - RS. REGA, Porto Alegre, v. 12, n. 2, p. 61 - 79, 2015.

PORTO-GONÇALVES, C. W. Globalização da Natureza e a Natureza da Globalização. ed 7. São Paulo: Civilização Brasileira, 2017.

SCHIRMER, M.; LESCHIK, S.; MUSOLFF Current research in urban hydrogeology - A review. Advances in Water Resources 51, 2013. p. 280-291. doi: http://dx.doi.org/10.1016/j.advwatres.2012.06.015

TAJRA, A. A. Aspectos técnico-construtivos dos poços tubulares e a legislação pertinente. Área Piloto de Fortaleza-Ceará. Dissertação (Mestrado). Fortaleza: Centro de Ciências - UFC, 2001.

TUBAU, I.; VASQUEZ-SUÑE, E.; CARRERA, J.; VALHONDO, C.; CRIOLLO, R. Quantification of groundwater recharge in urban environments. Science of Total Environment, [s.l.] v. 592, p. 391 - 401, may. 2017.

VEYRET, Y. Os Riscos: o homem agressor e vítima do meio ambiente. São Paulo: Contexto, 2007.

WILHELM, S. R.; SCHIFF, S. L.; ROBERTSON, W. D. Biogeochemical Evolution of Domestic Wastewater in Septic Systems: 2. Application of Conceptual Model in Sandy Aquifers. Ground Water, v. 34, n. 5, p. $1-12.1996$.

WORLD HEARTH ORGANIZATION - WHO, Guidelines for water quality, Geneva: UNICEF/World Heath Organization, 2011,

ZHANG, Q.; SUN, J.; LIU, J.; HUANG, G.; LU, C.; ZHANG. Driving mechanism and sources of groundwater nitrate contamination in the rapidly urbanized region of south China. Journal of Contaminant Hydrology, n. 182, p. 221-230. 2015. doi: http://dx.doi.org/10.1016/j.jconhyd.2015.09.009 